\title{
50 Years of Systems Analysis of Energy Development In The USSR And Russia
}

\author{
A. A. Makarov
}

Energy Research Institute, RAS, Moscow, Russia

\begin{abstract}
This year replete with so many anniversaries related to the energy sector sees the centenary celebration of the GOELRO Plan. This event is remarkable for energy studies: a complex energy method that backed up the Plan development half a century later became one of the preconditions for the development of the methodology of systems analysis of the energy development. The groundwork of this methodology was laid at SEI/ESI SB RAS (Siberian Energy Institute. Melentiev Energy Systems Institute of the Siberian Branch of the Russian Academy of Sciences) founded by Academician L.A. Melentiev; the institute celebrates its 60th anniversary this year. Half a century ago, an 'off-site' department of the SEI was established in Moscow and 15 years later it was reorganized into ERI RAS (Energy Research Institute of the Russian Academy of Sciences) and GKNT (State Committee for Science and Technology).

The paper focuses on the background of the development of the theory and methods of systems analysis of energy development, covers its main theoretical and applied contributions in two stages of social and economic development of the country, discusses evolution of this research area and its possible adoption in the alternative (mobilization-type and liberal) concepts of shaping 'the information society' of the future.
\end{abstract}

Index Terms - GOELRO plan; systems analysis of the energy sector; methods and applications; further research directions.

\footnotetext{
* Corresponding author.

E-mail: makarov_ire@zmail.ru
}

http://dx.doi.org/10.38028/esr.2020.02.0006

Received June 01, 2020. Revised June 20, 2020.

Accepted July 28, 2020. Available online October 21, 2020.

This is an open access article under a Creative Commons Attribution-NonCommercial 4.0 International License.

(C) 2020 ESI SB RAS and authors. All rights reserved.

\section{INTRODUCTION}

The first-ever long-term outlook of the energy development as treated in conjunction with the economy, the plan of the State Commission for Electrification of Russia (GOELRO Plan) [1], proved a game-changer in managing the economy. Materials backing up the Plan attest to the back then advanced statements of scientific problems and techniques for validation of efficient solutions. Sixty years later, L.A. Melentiev would note that the GOELRO Plan laid foundations of "...the main ideology behind economic planning based on scientific understanding of the energy industry as a unified whole and electrification as the key driver of economic development" [2].

Harsh experience of Stalin's five-year plans, the Second World War, and restoration of the national economy that followed all demonstrated the huge mobilization potential of the planned economy and that of its fuel-and-energy basis but failed to contribute to any breakthroughs in the development of the methodology and means of planning. As late as in the mid-1960s the conditions for a quantum leap in methods and tools for planning the energy development as a prerequisite for economic development, namely:

- The awareness of the energy industry as an aggregation of processes of production, conversion, distribution, and consumption of energy resources (fossil fuels, hydropower, wind and solar energy, etc.) and all types of energy on a par with understanding the energy balance as a method for the complex quantitative and qualitative depiction of the production and consumption of all types of energy and fuels in the national economy as a whole, its industries, and the country's districts [3];

- The mathematical theory and methods developed by L.V. Kantorovich for searching the extreme points of convex functions in the multi-dimensional space of linear constraints and their economic interpretation [4] opened the way to stating and solving challenging problems of the optimum management and planning of economic development, including optimization of fuel and energy balances; 




1 Models of Russia's energy sector development as part of the world energy

2 Models of the energy industry impact on economic development as an integral part of the latter

3 Methods for optimization of LES development under uncertainty

4 Decomposition of LES development models with reconciliation of the primal and dual solutions, and use of the iterative aggregation method

5 Optimality criteria for LES development: comparing running and capital costs against each other, factoring in other criteria as constraints

6 Modeling the dynamics of LES development and operation modes

7 Modeling area-specific energy balances, technologies, transportation links, economy (costs and results), and constraints put on LES development

8 Concept and theory of systems analysis of energy industry development



\section{Model for development of the EP and the CP for SEP}

II Energy sector" subsystem ASPS by Gosplan of the USSR

III MIS for drafting documents on strategic energy development in Russia

IV MIS 'SCANER'

Fig. 1. Evolution underwent by the methodology and application of systems analysis of the development of large energy systems in the USSR and Russia.

Legend: I - Long-term energy program of the USSR; Comprehensive program for scientific and technological progress in the USSR; II - Automated system for planned calculations by the USSR Gosplan; III - Modeling-and-information system; IV-Supersystem for energy-related decision analysis. 
- The introduction of computers [5], their application to research and development reduced computational efforts needed for implementation of the first (calculation of energy balances of production and consumption for all types of energy resources throughout the country) and especially so of the second prerequisites (optimization of the above processes in the course of energy sector development and operation).

The novel methodological and computational basis made the 1960s the "Sturm und Drang" age in the development of economic and mathematical models and methods for optimization of decisions, on a par with efforts to apply them to the country's energy industry management. Researchers at the Siberian Energy Institute of the Siberian Branch of the USSR Academy of Sciences proposed a mathematical model for optimum energy development planning that was adapted to industries of the energy sector and country's regions.

\section{THEORY, METHODS, AND APPLICATIONS OF SYSTEMS} ANALYSIS OF THE ENERGY DEVELOPMENT IN THE USSR

Methodologies behind systems analysis study such objects and phenomena of the real world that:

Possess properties of the whole that cannot be reduced to a sum of properties of their elements;

Have elaborate internal and external relations and synergy effects of interrelations of elements that constitute the main factors of the system's efficiency growth: concentration, centralization, combination, and specialization of the main components of their economic activity;

Include an object, organizational bodies, and mechanisms (including financial ones) of control that are, as a rule, have a sophisticated hierarchical structure;

Obey the principle of least action, which requires optimization of the decisions to be made;

Have an uncertain future, which generates risks with respect to decisions made and requires adaptive control over their operation and development.

Identification of a mix and interrelations of systems that serve as a backbone of human activities by supplying all types of energy and the study of their current state and prospects to improve their efficiency are the subject of energy systems analysis. Focus on the mathematical statement (modeling) of a specific problem while factoring in all its aspects and relations underlies the methodology for systems studies in general and for those of energy development in particular.

It took several years to correctly represent the diversity of fuel and energy types, sources of their production, transportation routes to consumers, the variety of technologies and modes (daily, weekly, yearly) of their production, processing, and consumption in terms of a formal linear programming problem solved by the L.V. Kantorovich [4] method. It was even more difficult to formalize the unfolding of those processes in time to take into account the renovation and decommissioning of operating plants and construction of new ones, which, in turn, required a description of products and processes in the linked economic sectors. The optimum solution to this enormously complex problem had to be searched under uncertain values of all the numerical indicators used in the model (Fig. 1). The complete problem statement does not exist, and up to the early 1970s, we saw the chaotic proliferation of the problems of optimization of different parts of energy industry development.

An All-Union Symposium held at the SEI in 1970 initiated the process of creating the theories and methods of systems analysis of energy industry development. Large energy systems (LES) were construed as hierarchically organized man-machine systems of complex structures that operated under incomplete information [6]. Dozens of articles and local publications followed, they discussed theoretical problems, methods, and tools (mathematical models) for studying the LES structures and properties and solving a wide range of problems related to their development. Scientific and methodological aspects of those works as applied to the optimum planning of energy development were generalized in the monograph [7], and the possibility of their use in planning and engineering were first formalized in guiding documents. Efforts to build the automated system for plan calculations (ASPC) of the USSR Gosplan (State Planning Committee) opened the way to a radical change in the economic development planning, and the energy industry was a leader in the development of systems of cross-industry complexes.

As a result, by the end of the 1970s, a coherent and full-fledged school of systems research as applied to the energy industry was established in the USSR. The focus of the research was on the current state of the energy sector and power industry of the USSR and prospects for their development for 10-15 years, the features of fuel supply to the country's regions. The research also involved an analysis of the stability of marginal fuel costs by country' region, and the identification of values to be recommended as a tool for coordinating the results of various fuel and energy calculations in the energy sector subject to its optimum development. The systems approach extended its scope to control over the development of the electric power and heat industries, to the nuclear energy system, to gas supply systems, and to relations between energy and economic development. Preparation for the adoption of systems analysis methods for energy development was finalized by the elaboration of the first phase of the "Energy sector" subsystem of the ASPC of the USSR Gosplan.

The active involvement of Soviet experts in the energy project hosted by the IIASA (founded in 1972) attested to the leading role the USSR played in the development of the theory and methods for systems analysis of energy industry development.

Methods and models for systems analysis of the energy industry development were tested back in 1979-1980 during 
the development of the USSR Long-term Energy Program. Different scenarios of optimal energy development to 2000 were computed at the central computing facility of the USSR Gosplan and analyzed in terms of their impact on the national economy. The findings of those studies were generalized in an aggregated form in [8] and included in commitments of the subsequent five-year plan of the USSR national economy development. They established themselves as prescriptive with methodological guidelines on the identification and use of reduced and marginal fuel and energy costs and on feasibility studies of engineering solutions in energy under the uncertainty of input data. The experience thus gained was reflected in SEI and ERI research monographs on theoretical grounds of systems analysis in the energy industry, on methods for studying and controlling energy systems, and on solutions to challenges of the country's energy development [9-11].

However, by the mid-1980s the USSR lost its leading positions in the development of methods and tools (especially in terms of computer performance) for systems analysis of the energy industry development. The USA came up with the national energy model MARKAL, and the International Energy Agency adopted these and more and more powerful means of systems analysis for projections of the energy development in the world and its regions.

At the end of the 1980s, the Comprehensive Program for Scientific and Engineering Progress (section "The Energy Sector") was developed with the aid of systems methods that provided for the minimization of green gas emissions by the energy industry and investigated the survivability of large energy systems. The continuous economic slowdown and radical change in the foreign policy of the country at the end of the 1980s, however, devaluated the main provisions and projections of the USSR Energy Program.

An analysis of the results of applying the methods and systems analysis of the energy development in the USSR leaves a mixed impression. Theoretically, they were immanent to the system of centralized planning and were successfully used for elaborating long-term programs of energy and technological development. However, the development of the most significant (annual and five-year) plans of energy development using the ASPC in GOSPLAN focused on validating the contingency calculations only. Hopes of the 1970s that the methods of systems analysis would accelerate the economic growth were not fulfilled. Poor economic discipline in the 1980s following the market reform championed by A.N. Kosygin and growing distortion of reported information by enterprises defied the purpose of using formalized methods for energy development planning.

\section{METHODS AND APPLICATIONS OF SYSTEMS ANALYSIS}

\section{TO THE ENERGY SECTOR DEVELOPMENT IN RUSSIA}

The USSR collapse with the transition of Russia to a market economy dismantled the system of planned economy and its organizational bodies. As early as in
1992, the Academy of Sciences developed (in a joint effort with the Ministry of Energy) the Conceptual foundations of Rusia's energy policy in a new economic environment, which was adopted by the Government. Methods and tools of systems analysis of energy development started to be adapted to market conditions (Fig. 1).

Those studies favored the development of Russia's energy strategy to 2010 (ES-2010) and identified the roles of energy sector industries in the medium-term program of economic development in Russia, in the former USSR countries, in shaping the Eurasian energy space, and in ensuring the energy security of Russia.

The increased role the energy sector played in the economy of the country and the challenges of reforming it called for changes in the policy documents. Russia's energy strategy to 2020 (ES-2020), along with energy sector development problems under market conditions focused on energy efficiency and security, the regional energy policy, and on the environmental issues.

Monitoring of ES-2010 and ES-2020 implementation demonstrated that scenarios and projections of the energy sector and its industries development adopted in the Program were met by five-year plans by $82 \%$ and $80 \%$, respectively. Projections of subsequent strategic documents were, unfortunately, met to a much lesser extent.

The transition to market relations was instrumental in having the capabilities of Soviet methods for systems analysis of energy development to be adjusted and expanded, while computer technology enhancement (especially the availability of more powerful personal computers interconnected into networks) allowed the development of larger and more sophisticated (by an order of magnitude) mathematical models. Bulky optimization models were framed and completed by simulation models created by experts for working in their specific fields. Distributed databases ensured the integration of numerous individual models into a single tool of systems analysis of energy industry development.

Russia's energy strategy to 2020 was developed using the novel modeling-and-information system StraTEK (Fig. 1). With the abandonment of the centralized planning system, the energy experts lost the required information sources on economic development and there were no historical data in the country that could prove adequate for proper application of statistical methods of forecasting. For this reason, the toolkit of systems analysis of energy development was to be supplemented by a full-blown system of economic development models.

New economic conditions called for a significant extension of mathematical models of development of the energy sector industries. Previously, their purpose was the optimization of development and utilization of the production capacities and relations, while in the new contexts, they were to optimize financial flows and organizational structures of the energy sector and major companies. This fact necessitated the transition from 
multi-dimensional problems of linear programming to non-linear problems of larger dimensionality to be able to study the options of forming energy markets and reforming natural monopolies, primarily in the electric power and gas supply industries.

The perfection of the organizational structure of the energy sector and shaping the competitive environment in gas and electric power industries served as major drivers of the structural policy of ES-2020. Those recommendations, however, were implemented to a lesser extent than projections of the development of industries that made up the energy sector.

The world economic crisis of 2008 crashed the GDP of the country by almost $8 \%$, the production of energy resources fell by $5 \%$, thus crowning the 'golden decade' of the development of Russia's economy and energy. The change in the country's leadership led to the substitution of the earlier objectives of accelerated economic growth for a paradigm of sustainable development. Works on the planning of energy industry development constituted little more than a proforma effort, and the market-oriented transformation of the industry was substituted for the state capitalism gaining momentum. Russia's energy strategy to 2030 was approved by inertia, but its scenarios of economic development happened to be too optimistic, which made projections of domestic fuel and power demand unrealistic and hence distorted the outlook of the energy sector development.

Fewer commissioning contracts as initiated by authorities and the global economic crisis revived the interest in methodological studies, notably, in projecting the relations between energy and economy and in the prospects of the world energy development. The ERI RAS completed the development of the SCANER modelingand-information system. It complemented StraTEK with models on the development of the world energy and energy markets and was regularly used for projecting the coordinated energy development in Russia and the world to 2035-2040. Special attention was paid to the dynamics of European and Asian fuel markets that are of primary importance for the country.

In 2014, Russia eventually adopted the law on strategic planning to regulate the body and contents of planning processes in the country. Mostly satisfactory fulfillment of provisions and compliance with the scope and deadlines for development of high-level strategic documents that were provided for by that law were in contrast to slow implementation of provisions on planning the development of the economy and its sectors, the energy industry in particular. The revision of the energy strategy to 2030 (initiated in 2013) and its extension to 2035 were not supported by real-time projections of the social and economic development of the country. The Government lost interest in the studies on perfecting energy markets and energy security, which diminished the number of contracts for such research. As a result, academic efforts focused on the generalization of ten-year results of using the methods and models for the energy industry development and on validating the long-term projections of the energy sector development.

Description of the development of production and economic systems as a manifold of agent-based models and their application within SCANER to medium- and longterm projections of the energy development in interaction with other sectors of the economy proved a breakthrough. The authors investigated the methods and 'cost' of energy adaptation to post-crisis economic development; outlined the foundations of economic aspects and management of the present-day electric energy industry of Russia; and discussed the impact of technological progress on the world energy development and the intensification of the transition from fossil fuels to carbon-free energy resources. Threats to energy development (reduction in fuel exports) and the Russian economy conditioned by those factors were estimated, and measures to mitigate their negative impact were proposed.

However, the recently adopted Energy strategy of Russia to 2035 neglected those results.

\section{WHAT ARE THE PROSPECTS?}

Systems analysis of the energy industry development is appealing, but its results are used poorly and spontaneously. This fact is demonstrated in Table 1, where 16 rows of the main body of works on planning the energy and economic development are grouped based on three aspects: stages and means of planning, sources of the required information, and the body of deliveries of the planning process.

As was noted, the application of systems methodology in the energy industry under socialism failed to go beyond the development of proposals on long-term plans and optimization calculations to accompany the five-year plan in the USSR Gosplan (see Column 1).

Under state capitalism, the use of tools of systems analysis (mathematical models) for the planning of the energy industry development in Russia extended to the development (once in every five years) of the national energy strategy, master plans, and programs of longterm energy sector development and included drafting of corporate strategies of the companies partially owned by the state. All the levels of planning are currently supported by computers, email, and the Internet. Large companies make planning decisions based on their projections of the market dynamics (Column 2 in Table 1).

According to the law, strategic economy and energy planning in Russia was re-oriented from standardized planning (the detailed plan for each enterprise) to indicative planning of the development objectives, tasks, and means for their achievement given a limited mix of quantitative indicators of the plan implementation success. The forecasting activity in the USA in the 1990s was organized in this very manner. In the early 21 st century, China changed over to a similar concept of strategic 
Table 1. Aspects and stages of applying systems analysis to the energy industry development*.

\begin{tabular}{|c|c|c|c|c|c|}
\hline \multirow{3}{*}{\multicolumn{2}{|c|}{$\begin{array}{l}\text { Aspects and the make-up of works on } \\
\text { development management }\end{array}$}} & \multicolumn{4}{|c|}{ Stages of the evolution of society } \\
\hline & & \multirow{2}{*}{$\begin{array}{l}\text { Planned economy } \\
\text { (the USSR, } \\
\text { S1980-1991) }\end{array}$} & \multirow{2}{*}{$\begin{array}{l}\text { State capitalism } \\
\text { (Russia, 2000-2020) }\end{array}$} & \multicolumn{2}{|c|}{ Information society (2035-2050) } \\
\hline & & & & Mobilization-type & Liberal \\
\hline \multirow{7}{*}{$\begin{array}{l}\text { Stages and } \\
\text { means of } \\
\text { planning }\end{array}$} & Level of detail of plans & $\begin{array}{l}\text { Down to individual } \\
\text { companies }\end{array}$ & State, ministry & $\begin{array}{l}\text { Planning down to } \\
\text { households }\end{array}$ & No planning \\
\hline & $\begin{array}{l}\text { Application of } \\
\text { mathematical models }\end{array}$ & Gosplan, ministries & $\begin{array}{l}\text { From the country } \\
\text { down to companies }\end{array}$ & \multirow{2}{*}{$\begin{array}{l}\text { A set of energy } \\
\text { development models } \\
\text { and/or artificial } \\
\text { intelligence }\end{array}$} & \multirow{2}{*}{$\begin{array}{l}\text { Agent-based } \\
\text { models of energy } \\
\text { and economy } \\
\text { entities } \\
\end{array}$} \\
\hline & Use of computers & Sporadic & Same & & \\
\hline & Communication means & Mail, telephone & $\begin{array}{l}\text { Mail, telephone }+ \\
\text { Internet }\end{array}$ & Super Internet & Super Internet \\
\hline & $\begin{array}{l}\text { Approval of decisions in } \\
\text { the energy industry }\end{array}$ & $\begin{array}{l}\text { State, ministry, } \\
\text { companies }\end{array}$ & State, ministry & $\begin{array}{l}\text { From the national level } \\
\text { to households }\end{array}$ & \multirow{2}{*}{$\begin{array}{l}\text { Modeling the } \\
\text { market operation } \\
\text { under incomplete } \\
\text { information }\end{array}$} \\
\hline & $\begin{array}{l}\text { Factoring in energy and } \\
\text { economy relations }\end{array}$ & Ministry (detailed) & Ministry (aggregated) & $\begin{array}{l}\text { Integration of energy into } \\
\text { the economy }\end{array}$ & \\
\hline & $\begin{array}{l}\text { Approval of planned } \\
\text { decisions }\end{array}$ & Ministry & State, companies & Top management level & Decentralized \\
\hline \multirow{3}{*}{$\begin{array}{l}\text { Data } \\
\text { sources }\end{array}$} & From linked companies & Limited & Limited & \multirow{3}{*}{$\begin{array}{l}\text { Integral databases on } \\
\text { the energy industry, } \\
\text { subcontractors, and } \\
\text { consumers }\end{array}$} & \multirow{3}{*}{$\begin{array}{l}\text { Formed under } \\
\text { simulation of the } \\
\text { market operation } \\
\text { under incomplete } \\
\text { information }\end{array}$} \\
\hline & $\begin{array}{l}\text { From the upper level in } \\
\text { an aggregate form }\end{array}$ & Ministry & $\begin{array}{l}\text { Ministry + state-owned } \\
\text { company }\end{array}$ & & \\
\hline & Company's projections & Limited & $\begin{array}{l}\text { Most of the } \\
\text { companies }\end{array}$ & & \\
\hline \multirow{6}{*}{$\begin{array}{l}\text { Planning } \\
\text { deliveries }\end{array}$} & Prescriptive plan & For the most part & - & \multirow{4}{*}{$\begin{array}{l}\text { Optimized production } \\
\text { development plans and } \\
\text { setting of standards of } \\
\text { energy consumption }\end{array}$} & \multirow{4}{*}{$\begin{array}{l}\text { Market players } \\
\text { make planned } \\
\text { decisions and assess } \\
\text { development risks }\end{array}$} \\
\hline & Taxes & State & State & & \\
\hline & Prices & State & State (partially) & & \\
\hline & $\begin{array}{l}\text { Investment plans of } \\
\text { companies }\end{array}$ & Ministry & $\begin{array}{l}\text { Ministry for state- } \\
\text { owned companies }\end{array}$ & & \\
\hline & Economic rules & State & State & State & Economic council \\
\hline & Planning enhancement & Same & Same & Same & Same \\
\hline
\end{tabular}

*Aspects of planning activities that make use of the tools of systems analysis are given in bold.

planning of the economy (and the energy as its integral part). Implementation of the indicative economy and energy planning in Russia is impeded by the biased nature and low validity of the drafted documents along with the process casuality as mentioned above. All the hierarchy of indicative planning in the USA (and, to a much lesser extent, in China) is accompanied by publicly discussed modeled projections that are developed by well-funded powerful research organizations on a competitive basis. Justification of economy and energy development strategies and programs in Russia is of fragmented nature (they are validated mainly by academic institutions weakened by the reform), their optional discussion is a mere formality and is mainly ignored in the planning documents.

Meanwhile, the development of 'digitalization' concepts and programs for the industries and companies in Russia to 2024, which started recently, is aimed at acquiring and identifying accessible information and using it only in the operational management of the company or sector of the economy. The fourth (digital) technological revolution, however, leaves no alternatives to the broad adoption of methods and means of systems analysis for managing the economic development in general and that of the energy industry in particular.

Let us consider the alternative concepts of applying the systems methodology and tools to the planning of the development of the energy sector ( 15 to 25 years ahead) as a constituent part of the country's economy, omitting the social implications of the information society.

Given an unfavorable geopolitical situation, the mobilization-type digital economy may be formed in certain countries when centralized planning extends down to households (see Column 3 in Table 1). Plans for the economic (and energy) development within this concept are computed by the computer networks using megasystems of production and area-specific mathematical models. Input information for the models is obtained using neural networks based on the databases of reported data and assessment of their errors. Following the results of optimization calculations, other neural networks will generate representative scenarios of systems development and will form a prescriptive matrix of indicators corresponding to them. On this basis, the authorized bodies make decisions that are automatically disaggregated into production and investment plans, prices and taxes for the companies, and consumption standards for the population.

An alternative concept is that of liberal economy and it reflects the optimistic outlook [12] of experts with respect to development trends and adoption of information technology (see Column 4 in Table 1). It implies the lack of even an indicative plan and availability of the selforganization of all the market players in the sophisticated 
process of managing the future. Input information for these is acquired with the help of neural networks and subsequently used for the development (in computer networks) of a set of economic development scenarios based on the manifold of agent-based models of market players. Based on those scenarios, the Market Moderator (Economic Council) forms a preferred (in terms of criteria of maximum volume and growth quality given minimum system risks) high-low lines of economic development (including the energy industry). Each player, as a decentralized independent company (DIC), can control all the information processes and identify its probable future risks using blockchain technology [13]. Collegial bodies of the market adjust the rules of its operation and perfect requirements to be met by the tools.

Thus, with the liberalized digital economy, the longestablished methods of analysis should be complemented with the following:

- Neural networks, pattern recognition techniques, and other artificial intelligence means;

- Agent-based models and methods of agent interaction;

- Blockchain technology.

The extent of implementation of this concept remains uncertain, but mastering the means described above would enhance the methodology of systems analysis of energy industry development as an integral part of the economy and the production base of the society.

\section{REFERENCES}

[1] Plan of the Electrification of the RSFSR. 2nd edition. Moscow: Gospolitizdat, 1955. (in Russian)

[2] Melentiev L.A. Essays on the history of the national energy sector. Moscow: Nauka, 1987. (in Russian)

[3] Melentiev L.A., Shteingauz E.O. The USSR Energy Economy, M.; L.: Gosenergoizdat, 1959, 1963. (in Russian)

[4] Kantorovich L.V. The best use of economic resources. Moscow: Akademizdat, 1960. (in Russian)

[5] Glushkov V.M. Synthesis of digital machines. Moscow: Fizmatgiz, 1962. (in Russian)

[6] Optimization and control in large energy systems. Vol. 1. Edited by L.A. Melentiev, L.S. Belyaev. Irkutsk: SEI, SB of the USSR Academy of Sciences, 1970. (in Russian)

[7] Makarov A.A., Melentiev, L.A. Methods for energy optimization. Novosibirsk: Nauka, 1973 (in Russian)

[8] Energy Sector of the USSR. Edited by L.A. Melentiev, and A.A. Makarov. Moscow: Ekonomika, 1983. (in Russian)

[9] Theoretical grounds of energy systems analysis. Edited by L.S. Belyaev and Yu. N. Rudenko. Novosibirsk: Nauka, 1986, 335 p. (in Russian)

[10] Methods for analysis and control of energy systems. Edited by A.P. Merenkov, Yu. N. Rudenko. Novosibirsk: Nauka, 1978, 373 p. (in Russian)
[11] Complex problems of the USSR energy development. Edited by A.A. Papin, A.A.Makarov. Novosibirsk: Nauka, 1988, 287 p. (in Russian)

[12] Kelly K. Unavoidable. 12 technological trends that determine our future. M.: Mann, Ivanov and Ferber Co., Ltd., 2018. (in Russian, originally published in English in 2016).

[13] DAOstack - an operating system, for decentralized autonomous companies. Gibraltar: White Paper, 2017. (in Russian)

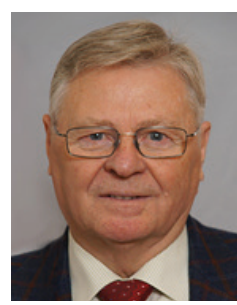

Alexey Alexandrovich Makarov is Academician of RAS, RAS Advisor, graduated from Kalinin Leningrad Polytechnic Institute with a degree in Economics and Energy Management. Main directions of activity: Methods of systems research in energy, development of energy policy, forecasting the development of the fuel and energy complex of the country and regions, interaction of energy with the economy and the environment 